\title{
Comparative Analysis of Solar Cell Efficiency between Monocrystalline and Polycrystalline
}

\author{
Sugianto ${ }^{1, a}$ \\ ${ }^{1}$ Department of Electrical Engineering, Muslim University Indonesia, Sumohardjo Street, Makassar, 90231, Indonesia \\ a Puangsugianto@gmail.com
}

\begin{abstract}
The output power capacity of solar panels depends on the intensity of light radiation it receives, while the life time depends on the high and low temperatures experienced. The purpose of this study was to examine the effect of light intensity on the output power and efficiency of solar panels. This study applies a direct measurement method using a monocrystalline type solar panel and a polycrystalline type with the same power capacity with a peak capacity of $50 \mathrm{Wp}$. The research was conducted indoors using lights as light sources by varying the light intensity in the range $2.21-331.01 \mathrm{~W} / \mathrm{m}^{2}$ with a distance of 50 $\mathrm{cm}$ from the light source from the solar panel. The increase in temperature on the surface of the solar panel can also reduce the power capacity generated, and the monocrystalline type is more resistant to temperature increases than polycrystalline. The efficiency of the solar panel changes when given light with a certain energy, up to the highest intensity of $331.01 \mathrm{~W} / \mathbf{m}^{2}$, with the highest temperature that occurs resulting in an efficiency of $12.84 \%$ on the Monocrystalline Panel and $11.95 \%$ on the Polycrystalline Panel.
\end{abstract}

Keywords-Efficiency, solar panels, $50 \mathrm{Wp}$, monocrystalline, polycrystalline

\section{Introduction}

A semiconductor material composition in the form of a p-n (positive-negative) diode meeting, if it gets a light beam it will cause a flow of electrons in it, so it is called a Solar Cell which can be used as a source of electrical energy. The sun is the strongest light source that can be used as a source of light rays in solar cells, so solar cells are often referred to as photovoltaic cells, on the other hand, photovoltaic cells can be interpreted as "lightelectricity". To meet the electron flow capacity as needed, a number of solar cells are combined in a certain area called the solar panel. The transfer of electrons or the so-called current flow between two layers of photovoltaic cells which are opposite in the solar panel due to exposure to sunlight is called the photovoltaic effect.

Solar panels are the most effective, sustainable and environmentally friendly power generation system in the world today. Various types of solar panel technologies such as mono crystalline silicon, poly crystalline silicon, amorphous silicon, thin films are the most popular technologies for generating electricity. The performance and efficiency of solar panel modules depend on the electrical parameters and the environment in which they are located [1].

The sun never stops emitting its rays but the availability of sunlight in various parts of the earth varies greatly with different environmental temperatures and atmospheric conditions so that the MPP (Maximum Power Point) of the solar panels is unstable. Therefore, an MPPT (Maximum Power Point Tracking) controller is needed to operate the solar panel at its MPP [2]. In recent years, various methods have been developed to track the MPP, to orient the solar panels in the right sunlight to maximize the output power of the solar panels, regardless of temperature conditions, radiation and electrical load characteristics [3].

The temperature of the PV module is a function of the incidence of radiant power density, electrical power output and thermal properties of the semiconductor materials used in the manufacture of the module. Only part of the solar spectrum is converted into electricity, while the rest is dissipated as heat. This heat causes the module temperature to rise which results in a decrease in module efficiency and output power [4]. 
The environment affects the solar panel modules and in turn, affects the performance of the solar panels or the electrical energy generated. This study calculates the performance of solar panels with a single diode model using the Five Parameters method, that the most efficient and optimal type of solar panel is a monocrystalline solar panel [5].

This model is based on mathematical equations and is described via an equivalent circuit including a photo current source, diode, series resistor, and shunt resistor. The developed model allows prediction of the behaviour of solar panel cells under different physical and environmental parameters [6]. Fundamental mathematical equations based on the equivalent series of photovoltaic cells are used to prepare the model. This model shows the overall performance of the photovoltaic cell characteristics by analyzing various types of electrical and environmental parameters [7].

Comparative studies of commercial solar panels under natural sunlight conditions resulted in an increase in the average maximum power for monocrystalline silicon panels varying from 1.9 times for low radiation to 2.4 times higher than that obtained from amorphous silicon panels, during the test period. Monocrystalline silicon panel temperature is lower than amorphous silicon panel temperature in most of the measurements [8].

The main problem with the use of solar panel modules that have been circulating in the market today is the level of efficiency and life time of each type of module to changes in weather or the environment, both during the dry season and during the rainy season. For this reason, a comparative analysis of the efficiency and life time of monocrystalline and polycrystalline solar panels is carried out so that they can become a guideline for the design of using these solar panels.

\section{Research Methodology}

\section{A. Solar radiation}

The sun is one of the stars which becomes the main source of energy for life on earth. The source of solar energy comes from the fusion reaction of atoms, resulting in very high pressure and temperature. From this fusion reaction the sun produces enormous energy.
This energy is emitted to the earth in the form of electromagnetic waves. The sun emits light radiation of various wavelengths, ranging from ultraviolet radiation, visible light to infrared (infrared) from the electromagnetic spectrum. The amount of radiation energy received from the sun per unit area per unit time as a function of wavelength.

Solar energy that is transmitted has a wavelength ranging from 0.25 micrometers to 3 micrometers (for outside the earth's atmosphere), while for the earth's atmosphere it ranges from 0.32 micrometers to 2.53 micrometers. Only 7\% of this energy consists of ultraviolet (Air Mass 0), 47\% is visible (visible light has a wavelength of 0.4 micrometers to 0.75 micrometers), $46 \%$ is infrared light.

The conversion of solar energy into other energy can generally be divided into three separate processes, namely heliochemical, heliothermal and helioelectrical processes. The heliochemical process occurs in the photosynthesis process. This process is the source of all fossil fuels. The heliothermal process is the absorption (absorption) of solar radiation and is directly converted into thermal energy, while the main helioelectrical process is the production of electricity by solar cells and is also called the photovoltaic effect.

To measure the light intensity, a device called a lux meter is used. Lux meter is a tool used to measure light intensity or lighting level. Usually used indoors. The lighting needs of each room are sometimes different. Everything depends and is adapted to the activities carried out. To measure the level of lighting, a tool that can work automatically is needed to be able to measure light intensity and adjust to the light needed.

Measurement of light intensity using a Lux meter which produces a value of light intensity in units of lux. There is no direct conversion between lux and $\mathrm{W} / \mathrm{m}^{2}$ it depends on the wavelength or color of the light. So that to get the conversion between lux and $\mathrm{W} / \mathrm{m}^{2}$, it is necessary to experiment. However there is a conversion estimate of $0.0079 \mathrm{~W} / \mathrm{m}^{2}$ per lux.

The amount of daily radiation received by the earth's surface is shown in Figure 1 in the morning and evening, the radiation reaches the surface of the earth with a small 
intensity. This is because the direction of the sun's rays is not perpendicular to the earth's surface (forming a certain angle) therefore that sunlight experiences a diffusion event by the earth's atmosphere.

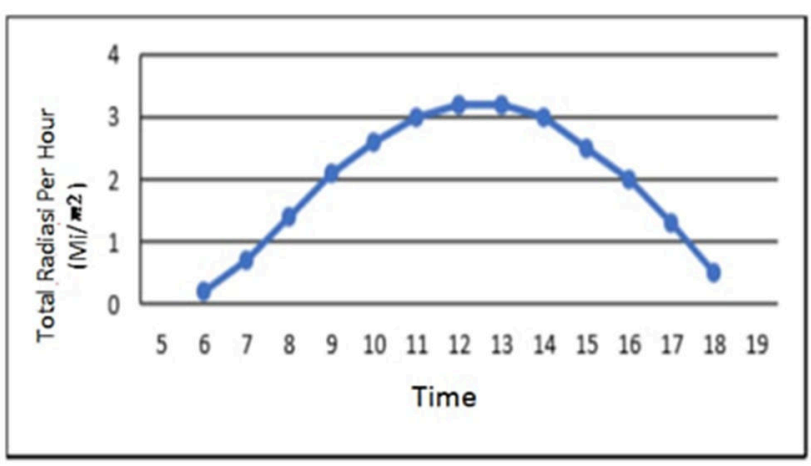

Figure 1 . The graph of daily solar radiation amount which hit the earth.

The amount of radiation received by the solar panel is strongly influenced by the angle of incidence, which is the angle between the direction of the incident rays and the perpendicular component to the plane of the panel. The panel will receive maximum solar radiation when perpendicular to the panel plane. When the direction of the sun is not perpendicular to the plane of the panel, the panel will receive less radiation.

\section{B. Types of solar cells}

The types of solar cells are classified based on their manufacturing technology. Broadly speaking, solar cells are divided into three types, namely:

\section{- Monocrystalline}

This type is made of thinly sliced pure silicon crystal bars. With technology like this, it will produce solar cell pieces that are identical to each other and high performance. So that it becomes the most efficient solar cell compared to other types of solar cells, around 15\% $20 \%$. The high price of pure silicon crystals and the technology used have resulted in the high price of this type of solar cell compared to other types of solar cells on the market. The drawback is that this type of solar cell if arranged to form a solar module (solar panel) will leave a lot of empty space because solar cells like this are generally hexagonal or round in shape, depending on the shape of the silicon crystal bars, as shown in the following figure.
Solar cells made of single crystal silicon have been widely used in everyday life, such as toys, clocks, calculators, water heaters to satellites. The lifespan of solar cells made from single crystalline silicon material is up to 50 years with a possible reduction in efficiency of $0.5 \%$ per year on average. Up to now, the use of single crystalline silicon solar cells is easy to find in urban areas and places with limited area.

\section{- Polycrystalline}

This type is composed by several silicon crystal rods which are melted and then poured into a square mold. The purity of the silicon crystals is not as pure as the monocrystalline solar cells, therefore the resulting solar cells are not identical to each other and the efficiency is lower, around $13 \%-16 \%$. It looks like there is a broken glass motif in it.

The square shape, if it is arranged to form solar panels, will be tight and there will be no wasted empty space like the arrangement of the monocrystalline solar panels above. The manufacturing process is easier than monocrystalline, therefore the price is cheaper. This type is most widely used today.
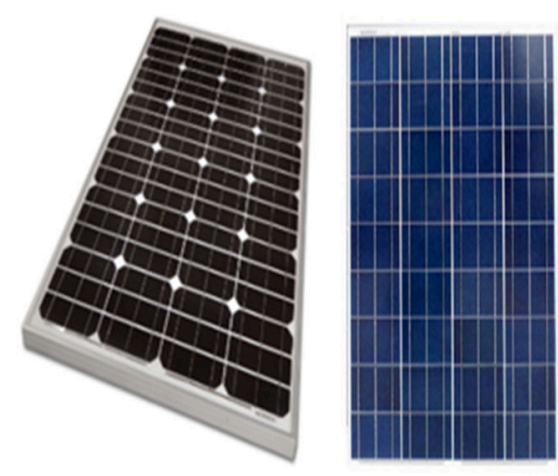

Figure 2. Monocrystalline and polycrystalline solar panel $50 \mathrm{wp}$ 
Table 1. Solar Cell Specification

\begin{tabular}{|l|l|l|}
\hline \multicolumn{1}{|c|}{ Parameter } & $\begin{array}{l}\text { PV Panel } \\
\text { Monokristalin } \\
50 \text { Wp }\end{array}$ & $\begin{array}{l}\text { PV Panel } \\
\text { Polykristalin } \\
50 \mathrm{Wp}\end{array}$ \\
\hline Ratec Max Power & $50 \mathrm{Watt}$ & $50 \mathrm{Watt}$ \\
\hline Power Telorance & $0-+5 \mathrm{~W}$ & $0-+5 \mathrm{~W}$ \\
\hline Max Power Voltage (Wmp) & $17.40 \mathrm{~V}$ & $17.40 \mathrm{~V}$ \\
\hline Max Power Current (Imp) & $2.85 \mathrm{~A}$ & $2.284 \mathrm{~A}$ \\
\hline Open Circuit Voltage (Voc) & $22.40 \mathrm{~V}$ & $22.40 \mathrm{~V}$ \\
\hline Short Circuit Current (Isc) & $3.04 \mathrm{~A}$ & $3.04 \mathrm{~A}$ \\
\hline Cell Effiency & $17.60 \%$ & $17.20 \%$ \\
\hline Junctrion box & IP65 & IP 65 \\
\hline Max System Voltage & $1000 \mathrm{~V}$ & $1000 \mathrm{~V}$ \\
\hline Max Series Fuse Rating & $10 \mathrm{~A}$ & $10 \mathrm{~A}$ \\
\hline Application Class & Grace A & Grace A \\
\hline
\end{tabular}

- The amount of incoming solar energy $\left(P_{\text {in }}\right)$

The amount of incoming solar energy can be done by calculating the intensity of the incoming solar light $\left(P_{\text {in }}\right)$, namely:

$P_{\text {in }}=\mathrm{I} . A_{\text {Panel }}$

Where :

$P_{\text {in }}=$ energy / power going into solar panels (Watts)

$A_{p}=$ panel surface area $\left(\mathrm{m}^{2}\right)$

$\mathrm{I}=$ the intensity of solar radiation at observation

$\left(\mathrm{W} / \mathrm{m}^{2}\right)$

- The amount of energy generated by Solar Cell Cell $\left(P_{\text {out }}\right)$

The amount of energy produced from the Pout solar panel can be calculated by measuring the voltage and output current of the solar panel, so that the energy produced is the output power of the solar panel, it can be found with the formula

$$
P_{\text {out }}=\mathrm{V} . \mathrm{I}
$$

where:

$P_{\text {out }}=$ Energy/output power from solar panels (Watts)

$\mathrm{V}=$ Voltage that occurs (Volt)

$\mathrm{I}=$ Current (Ampere)

- Efficiency value of solar panels

To calculate the efficiency value of solar panels, the following equation is used:

$n=\frac{P_{\text {out }}}{P_{\text {in }}} \times 100 \%$

Where:

$n=$ Efficiency of solar panels

$P_{\text {out }}=$ Maximum power

$P_{\text {in }}=$ energy $/$ power going into solar panels (Watts)

- Maximum Power Calculation

The calculation of Maximum Power $\left(P_{\max }\right)$ Which can be generated by a 50 WP Monocrystal Solar Cell Panel, namely [7], [9]:

$$
P_{\text {max }}=V_{o c} \cdot I_{S C} \cdot F F
$$

where:

$P_{\max }=$ maximum power

$V_{o c}=$ Open circuit voltage

$I_{s c}=$ Short circuit current

$F F=$ Fill factor

The most important parameter in the performance of a solar panel is the intensity of solar radiation or commonly referred to as solar irradiation, which is the amount of solar power coming to the surface per area. The intensity of solar radiation outside the Earth's atmosphere is called the solar constant, which is $1365 \mathrm{~W} / \mathrm{m}^{2}$. Filtered by the earth's atmosphere, some light is lost, and the peak radiation intensity becomes around $1000 \mathrm{~W} / \mathrm{m}^{2}$. This value is a typical radiation intensity on the surface perpendicular to the sun and in bright conditions. The magnitude of the solar irradiance value will determine the amount of power. that can be generated by a solar panel.

\section{Characteristics of Solar Cells}

The solar cell is a non-linear device, so to understand its characteristics a graph is used. The electrical 
properties of solar cells in generating electrical energy can be observed from the characteristics of these cells, namely based on the current and voltage generated by solar cells under different light and load conditions. The characteristics of solar panels consist of current-voltage curves and power-voltage curves [9].

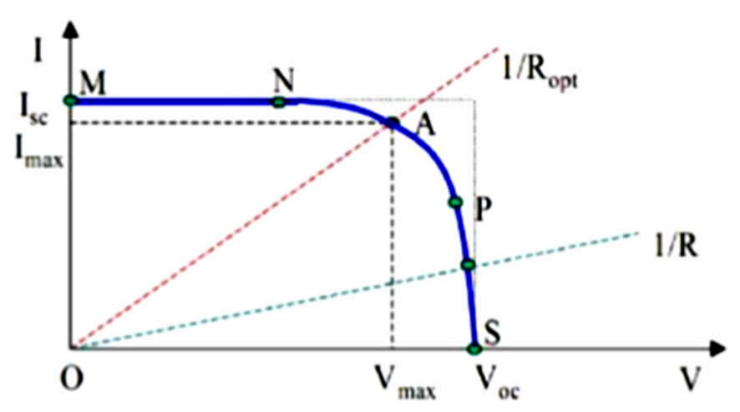

Figure 3. Voltage Current Curve

Figure 3 exhibits when the cell is connected to the load (R). Load poses resistance as a linear line with the line I / V = I / R. This shows that the power obtained depends on the resistance value. If $\mathrm{R}$ is small, then the cell operates in the $\mathrm{MN}$ curve region, where the cell operates as a constant current source or short circuit current (Isc). On the other hand, if R is large, the cell operates in the PS region, where the cell operates as a constant voltage source or open circuit (Voc) voltage. When connected to the optimal resistance $\mathrm{R}_{\mathrm{opt}}$ means the solar cell produces maximum power with maximum voltage (Vmax) and maximum current (Imax).

Parameters on the current-voltage curve, parameters commonly used to determine the output characteristics of solar cells, namely:

1. Short circuit current (Isc) is the maximum output current from the solar cell in the absence of resistance.

2. The open circuit voltage (Voc) is the maximum voltage capacity that can be reached in the absence of current.

3. The maximum power $(\operatorname{Pmax})$ in Figure 3 , is at point A (Vmax, Imax).
4. The fill factor or Fill Factor (FF) is a price that is close to the constant of a particular solar cell. If the FF value is higher than 0.7 , the cell is better off.

Fill factor is basically a measure of the quality of the solar cell. It is calculated by comparing the theoretical maximum power and output power at open circuit and short circuit voltages. The fill factor equation is Pmax/PT or (Imp x Vmp)/(Isc x Voc).

The simple equivalent sequence for a PV solar cell consists of a current source driven by sunlight in parallel with the diode.

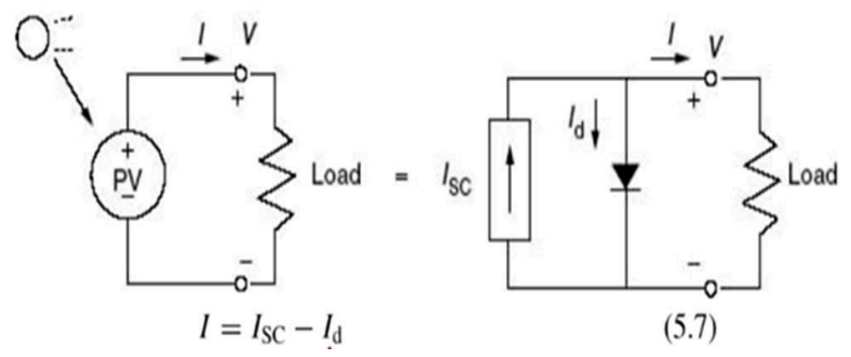

Figure 4. Solar cell equivalent sequence

Two important parameters for PV solar sell are Short-circuit current and Open-circuit Voltage.

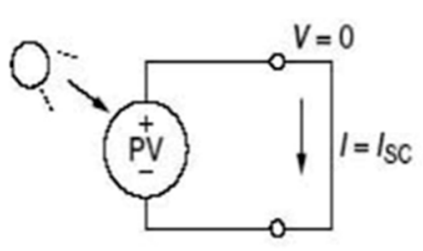

(a) Short-circuit current

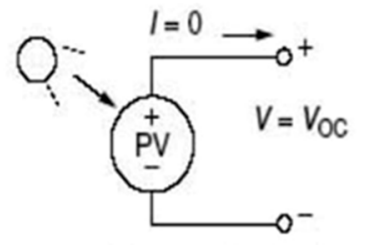

(b) Open-circuit voltage
Figure 5. Testing Series

D. 50 Wp Monocrystal Solar Cell Panel Data Analysis

1. Light intensity $313313 \mathrm{~W} / \mathrm{m}^{2}$

a. The amount of incoming solar energy $\left(P_{i n}\right)$ 
The amount of incoming solar energy can be done by calculating the intensity of the incoming light $\left(P_{\text {in }}\right)$, namely:

$$
P_{\text {in }}=I . A_{\text {panel }}
$$

where:

$P_{\text {in }}=$ energy $/$ power entering the solar panel (Watts)

$A_{\text {panel }}=$ panel surface area $\left(\mathrm{m}^{2}\right)$

$\mathrm{I}=$ intensity of light radiation at observation $\left(\mathrm{W} / \mathrm{m}^{2}\right)$

From the observations, the data obtained from each interval of the difference in light intensity from the minimum light to the maximum light. The data is then processed to determine the amount of incoming solar energy. For the first data, the calculations are as follows:

$$
\begin{gathered}
\mathrm{I}=313 \mathrm{~W} / \mathrm{m}^{2}, A_{\text {panel }}=0,361 \mathrm{~m}^{2} \\
\text { So : } P_{\text {in }}=\mathrm{I} . A_{\text {panel }}=313 \mathrm{~W} / \mathrm{m}^{2} \cdot 0,361 \mathrm{~m}^{2}= \\
112.99 \text { Watt }
\end{gathered}
$$

b. The amount of energy generated by Solar Cell

$$
\left(P_{\text {out }}\right)
$$

The amount of energy produced from solar panels can be calculated by measuring the voltage and output current of the solar panels, so that the energy produced is the output power of the solar panels, which can be found with the formula:

$$
P_{\text {out }}=V . I
$$

where:

$P_{\text {out }}=$ energy/output power from solar panels (Watts)

$\mathrm{V}=$ Voltage that occurs (Volt)

$$
\mathrm{I}=\text { Current (Ampere) }
$$

From the observations, the data obtained from each interval of the difference in light intensity from the minimum light to the maximum light. The data is then processed to determine the amount of incoming solar energy, for the first data, the Pout calculation is as follows:

$$
\begin{aligned}
& \mathrm{V}=18.58 \text { Volt } \\
& \mathrm{I}=0.72 \mathrm{~A}
\end{aligned}
$$

$$
\text { So }: P_{\text {out }}=V . I=18.58 \mathrm{~V} \cdot 0.72 \mathrm{~A}=13.37 \text { Watt }
$$

\section{c. Value of Efficiency}

The amount of efficiency produced by solar panels on battery charging can be calculated by first calculating the amount of incoming solar energy (Pin) and the amount of solar energy that comes out (Pout), so the efficiency obtained is the output efficiency of the solar panels on battery charging. The efficiency calculation is as follows:

$$
\begin{aligned}
& P_{\text {in }}=112.99 \mathrm{Watt} \\
& P_{\text {out }}=13.37 \mathrm{Watt}
\end{aligned}
$$

\begin{tabular}{|c|c|c|c|c|c|c|c|c|c|c|c|c|c|}
\hline \multirow[b]{2}{*}{ No } & \multirow[b]{2}{*}{ Waktu } & \multicolumn{2}{|c|}{ Monokristalin } & \multicolumn{2}{|c|}{ Polykristallin } & \multicolumn{2}{|c|}{\begin{tabular}{|l|} 
Temperatur \\
$(\mathbf{C} \wedge \mathbf{0})$
\end{tabular}} & \multirow{2}{*}{$\begin{array}{l}\text { It } \\
\text { (Watt } \\
\text { / } 2 \text { 2) }\end{array}$} & \multirow{2}{*}{$\begin{array}{l}\text { Pin }= \\
I^{+} \text {Aps } \\
\text { nel } \\
\text { (watt) }\end{array}$} & \multicolumn{2}{|c|}{ Pout $=V * I$ (Watt) } & \multicolumn{2}{|c|}{$\begin{array}{l}\text { Efisiensi } \\
(\eta)=\text { Pout Pin(\%) }\end{array}$} \\
\hline & & $\begin{array}{l}\mathbf{V} \\
\text { (Volt) }\end{array}$ & $\begin{array}{l}\text { I } \\
\text { (Ampe } \\
\text { re) }\end{array}$ & $\begin{array}{l}\mathrm{v} \\
\text { (Volt) }\end{array}$ & $\begin{array}{l}\text { I } \\
\text { (Amper } \\
\text { e) }\end{array}$ & T & $\mathrm{Ta}$ & & & $\begin{array}{l}\text { Monokr } \\
\text { istallin }\end{array}$ & $\begin{array}{l}\begin{array}{l}\text { Polykris } \\
\text { tallin }\end{array} \\
\end{array}$ & \begin{tabular}{l|}
$\begin{array}{l}\text { Monok } \\
\text { ristalin }\end{array}$ \\
\end{tabular} & $\begin{array}{l}\text { Polykr } \\
\text { istallin }\end{array}$ \\
\hline 1 & 08:00 & 18.58 & 0.72 & 18.5 & 0.84 & 28 & 28 & 313 & 112.99 & 13.37 & 15.54 & 11.83 & 13.75 \\
\hline 2 & 09:00 & 18.35 & 0.84 & 18.4 & 0.75 & 34 & 32 & 384 & 139 & 15.41 & 13.8 & 11.08 & 9.92 \\
\hline 3 & $10: 00$ & 19.69 & 1.01 & 19.83 & 0.97 & 36 & 35 & 425 & 153 & 19.88 & 19.23 & 12.99 & 12.56 \\
\hline 4 & 11:00 & 19.4 & 1.01 & 19.37 & 0.97 & 38 & 34 & 373 & 135 & 19.59 & 18.78 & 14.51 & 13.91 \\
\hline 5 & 12:00 & 18.25 & 0.81 & 18.34 & 0.72 & 38 & 36 & 288 & 104 & 14.78 & 13.2 & 14.21 & 12.69 \\
\hline 6 & $13: 00$ & 19.53 & 1 & 19.56 & 0.94 & 38 & 36 & 445 & 161 & 19.53 & 18.38 & 12.13 & 11.41 \\
\hline 7 & $14: 00$ & 19.82 & 0.98 & 19.99 & 0.9 & 37 & 35 & 415 & 150 & 19.42 & 17.99 & 12.94 & 11.99 \\
\hline 8 & $15: 00$ & 19.58 & 0.63 & 19.88 & 0.62 & 36 & 32 & 284 & 103 & 12.33 & 12.32 & 11.97 & 11.9 \\
\hline 9 & $16: 00$ & 19.4 & 0.76 & 19.8 & 0.76 & 34 & 34 & 329 & 119 & 14.74 & 15.04 & 12.38 & 12.63 \\
\hline 10 & $17: 00$ & 19.28 & 0.82 & 19.46 & 0.86 & 32 & 31 & 384 & 139 & 15.8 & 16.73 & 11.36 & 12.03 \\
\hline
\end{tabular}

\section{Efisiensi}

$$
\begin{aligned}
& =\frac{\text { Amount of out Energy }\left(P_{\text {out }}\right)}{\text { Amounty of in Energy }\left(P_{\text {in }}\right)} \times 100 \% \\
& =\frac{13.37}{112.99} \times 100 \%=11.83 \%
\end{aligned}
$$

Whereas for the intensity of $384 \mathrm{~W} /, 425 \mathrm{~W} /, 373 \mathrm{~W}$ /, $288 \mathrm{~W} /$ The calculation results can be seen in the following table 2 below.

\section{Results and Discussion}

A. Solar cell research results shown in the table 2.

Table 2, The Two Types of $50 \mathrm{Wp}$ Solar Cell Testing Using sunlight as an energy source.

Research table using 2 lamps 


\begin{tabular}{|c|c|c|c|c|c|c|c|c|c|c|c|}
\hline \multirow[b]{2}{*}{ No } & \multicolumn{2}{|c|}{ Monokristalin } & \multicolumn{2}{|c|}{ Polykristallin } & \multirow{2}{*}{$\begin{array}{l}\text { Temperatu } \\
\mathbf{r} \text { (C`o) } \\
\text { (C`) }\end{array}$} & \multirow{2}{*}{$\begin{array}{l}\text { It } \\
\text { (Watt/m } \\
\text { 2) }\end{array}$} & \multirow{2}{*}{\begin{tabular}{|l} 
Pin= \\
$I^{*}$ Apanel \\
(watt)
\end{tabular}} & \multicolumn{2}{|c|}{ Pout=V*I (Watt) } & \multicolumn{2}{|c|}{$\begin{array}{l}\text { Efisiensi } \\
(\eta)=\text { PoutPin(\%) }\end{array}$} \\
\hline & (Volt & \begin{tabular}{|l|} 
I \\
(Ampere)
\end{tabular} & $\begin{array}{l}\text { V } \\
\text { (Volt) }\end{array}$ & $\begin{array}{l}\text { I } \\
\text { (Ampere) }\end{array}$ & & & & $\begin{array}{l}\text { Monokrist } \\
\text { alin }\end{array}$ & \begin{tabular}{|l|} 
Polykr \\
istallin
\end{tabular} & $\begin{array}{l}\text { Monokris } \\
\text { talin }\end{array}$ & $\begin{array}{l}\text { Polykris } \\
\text { tallin }\end{array}$ \\
\hline 1 & 12.16 & 0.0016 & 12.14 & 0.0015 & 30.4 & 2.212 & 0.79 & 0.01 & 0.01 & 1.26 & 1.26 \\
\hline 2 & 13.11 & 0.0083 & 13.09 & 0.0078 & 31 & 18.99 & 6.85 & 0.10 & 0.10 & 1.45 & 1.45 \\
\hline 3 & 17.54 & 0.012 & 17.46 & 0.010 & 31.3 & 35.78 & 12.91 & 0.21 & 0.17 & 1.62 & 1.31 \\
\hline 4 & 17.72 & 0.031 & 17.52 & 0.029 & 31.7 & 52.57 & 18.97 & 0.54 & 0.50 & 2.84 & 2.63 \\
\hline 5 & 17.86 & 0.054 & 17.61 & 0.052 & 32.1 & 69.36 & 25.03 & 0.96 & 0.91 & 3.83 & 3.63 \\
\hline
\end{tabular}

Research table using 3 lamps

\begin{tabular}{|c|c|c|c|c|c|c|c|c|c|c|c|}
\hline \multirow[b]{2}{*}{ No } & \multicolumn{2}{|c|}{ Monokristalin } & \multicolumn{2}{|c|}{ Polykristallin } & \multirow{2}{*}{$\begin{array}{l}\text { Temperat } \\
\text { ur } \\
\left(\mathrm{C}^{\wedge} 0\right)\end{array}$} & \multirow{2}{*}{$\begin{array}{l}\text { It } \\
\text { (Watt'm } \\
\text { 2) }\end{array}$} & \multirow{2}{*}{$\begin{array}{l}\text { Pin= } \\
I^{\star} \text { Apan } \\
\text { el } \\
\text { (watt) }\end{array}$} & \multicolumn{2}{|c|}{ Pout=V*I (Watt) } & \multicolumn{2}{|c|}{$\begin{array}{l}\text { Efisiensi } \\
(\eta)=\text { PoutPin(\%) }\end{array}$} \\
\hline & $\begin{array}{l}\text { V } \\
\text { (Volt) }\end{array}$ & \begin{tabular}{|l} 
\\
(Ampere \\
)
\end{tabular} & $\begin{array}{l}\text { V } \\
\text { (Volt) }\end{array}$ & \begin{tabular}{|l} 
I \\
(Ampere \\
) \\
\end{tabular} & & & & $\begin{array}{l}\text { Monokris } \\
\text { talin }\end{array}$ & \begin{tabular}{|l} 
Polyk \\
ristalli \\
n \\
\end{tabular} & $\begin{array}{l}\text { Monokri } \\
\text { stalin }\end{array}$ & \begin{tabular}{|l}
$\begin{array}{l}\text { Polykn } \\
\text { stallin }\end{array}$ \\
\end{tabular} \\
\hline 1 & 18.12 & 0.073 & 17.76 & 0.065 & 32.6 & 87.85 & 31.71 & 1.32 & 1.15 & 4.16 & 3.62 \\
\hline 2 & 18.17 & 0.091 & 17.82 & 0.080 & 32.9 & 106.35 & 38.39 & 1.65 & 1.44 & 4.29 & 3.75 \\
\hline 3 & 18.21 & 0.107 & 17.94 & 0.099 & 33.4 & 124.85 & 45.07 & 1.94 & 1.77 & 4.30 & 3.92 \\
\hline 4 & 18.33 & 0.159 & 18.02 & 0.132 & 33.8 & 143.35 & 51.74 & 2.91 & 2.37 & 5.62 & 4.58 \\
\hline 5 & 18.38 & 0.212 & 18.11 & $\mid$\begin{tabular}{|l|l}
$\mid$ \\
$\mid$
\end{tabular} & 34.3 & 161.84 & 58.424 & 3.89 & 3.56 & 6.65 & 6.09 \\
\hline
\end{tabular}

Research table using 4 lamps

\begin{tabular}{|c|c|c|c|c|c|c|c|c|c|c|c|}
\hline \multirow{2}{*}{ No } & \multicolumn{2}{|c|}{ Monokristalin } & \multicolumn{2}{|c|}{ Polykristallin } & \multirow{2}{*}{$\begin{array}{l}\text { Temperatu } \\
\mathbf{r} \\
\left(\mathbf{C}^{\wedge} \mathbf{0}\right)\end{array}$} & \multirow{2}{*}{$\begin{array}{l}\text { It } \\
\text { (Watt/m2 } \\
)^{2}\end{array}$} & \multirow{2}{*}{ 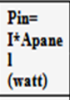 } & \multicolumn{2}{|c|}{ Pout $=V^{*} I$ (Watt) } & \multicolumn{2}{|c|}{$\begin{array}{l}\text { Efisiensi } \\
(\eta)=\operatorname{Pout} \operatorname{Pin}(\%)\end{array}$} \\
\hline & $\begin{array}{l}\text { V } \\
\text { (Volt) }\end{array}$ & $\begin{array}{l}\text { I } \\
\text { (Ampere) }\end{array}$ & $\begin{array}{l}V \\
\text { (Voltt) }\end{array}$ & $\begin{array}{l}\text { I } \\
\text { (Ampere) }\end{array}$ & & & & $\begin{array}{l}\text { Monokrist } \\
\text { alin }\end{array}$ & \begin{tabular}{|l|} 
Polykr \\
istallin
\end{tabular} & $\begin{array}{l}\text { Monokris } \\
\text { talin }\end{array}$ & $\begin{array}{l}\begin{array}{l}\text { Polykris } \\
\text { tallin }\end{array} \\
\end{array}$ \\
\hline 1 & 18.46 & 0.264 & 18.19 & 0.235 & 35.1 & 164.54 & 59.39 & 4.87 & 4.27 & 8.20 & 7.18 \\
\hline 2 & 18.61 & $\mid 0.317$ & 18.26 & 0.297 & 35.7 & 183.84 & $\mid 66.36$ & 5.89 & 5.42 & 8.87 & 8.16 \\
\hline 3 & 18.71 & 0.369 & 18.30 & 0.346 & 36.1 & 201.53 & 72.75 & 6.90 & 6.33 & 9.48 & 8.70 \\
\hline 4 & 18.81 & 0.422 & 18.33 & 0.401 & 36.8 & 220.03 & 79.43 & 7.93 & 7.35 & 9.98 & 9.25 \\
\hline 5 & 18.89 & $\mid 0.474$ & 18.42 & 0.452 & 37.2 & 238.53 & 86.01 & 8.95 & 8.32 & 10.4 & 9.67 \\
\hline
\end{tabular}

Research table using 5 lamps

\begin{tabular}{|c|c|c|c|c|c|c|c|c|c|c|c|}
\hline \multirow{2}{*}{ No } & \multicolumn{2}{|c|}{ Monokristalin } & \multicolumn{2}{|c|}{ Polykristallin } & \multirow{2}{*}{$\begin{array}{l}\text { Temperatu } \\
\mathrm{r} \\
\left.\mathrm{C}^{\prime} \mathbf{0}\right)\end{array}$} & \multirow{2}{*}{$\begin{array}{l}\text { It } \\
\text { (Watt/m2 } \\
)^{2}\end{array}$} & \multirow{2}{*}{$\begin{array}{l}\text { Pin= } \\
\text { I*Apane } \\
1 \\
\text { (watt) }\end{array}$} & \multicolumn{2}{|c|}{ Pout $=\mathrm{V} \star I\left(W_{\text {att }}\right)$} & \multicolumn{2}{|c|}{$\begin{array}{l}\text { Efisiensi } \\
(\eta)=\operatorname{Pout} \operatorname{Pin}(\%)\end{array}$} \\
\hline & $\begin{array}{l}\mathbf{Y} \\
\text { (Volt) }\end{array}$ & $\begin{array}{l}\text { I } \\
\text { (Ampere) }\end{array}$ & \begin{tabular}{|l|}
$\mathrm{V}$ \\
(Volt)
\end{tabular} & $\begin{array}{l}\text { I } \\
\text { (Ampere) }\end{array}$ & & & & \begin{tabular}{|l|}
$\begin{array}{l}\text { Monokrist } \\
\text { alin }\end{array}$ \\
\end{tabular} & $\begin{array}{l}\text { Polykgr } \\
\text { istallin } \\
\end{array}$ & \begin{tabular}{|l}
$\begin{array}{l}\text { Monokris } \\
\text { talin }\end{array}$ \\
\end{tabular} & $\begin{array}{l}\text { Polykgris } \\
\text { tallin }\end{array}$ \\
\hline 1 & 19.11 & 0.579 & 18.49 & 0.558 & 37.4 & 257.02 & 92.78 & 11.06 & 10.31 & 11.92 & 11.11 \\
\hline 2 & 19.18 & 0.632 & 18.56 & 0.618 & 37.9 & 275.52 & 99.46 & 12.12 & 11.47 & 12.18 & 11.53 \\
\hline 3 & 19.28 & 0.684 & 18.63 & 0.661 & 38.1 & 294.02 & 106.14 & 13.18 & 12.31 & 12.41 & 11.59 \\
\hline 4 & $\mid$\begin{tabular}{|l}
19.37 \\
\end{tabular} & 0.737 & 18.79 & 0.715 & 38.3 & 312.52 & 112.81 & $\mid \begin{array}{l}14.27 \\
\end{array}$ & 13.43 & 12.65 & 11.90 \\
\hline 5 & 19.46 & 0.789 & 18.86 & 0.758 & 38.8 & 331.01 & 119.49 & 15.35 & 14.29 & 12.84 & 11.95 \\
\hline
\end{tabular}

\section{B. Calculation of the maximum power of the Solar} Module

Calculation of Maximum Power (which can be generated by a 50 WP Monocrystalline Solar Cell Panel, namely:

Where :

$P_{\text {max }}=V_{o c} \cdot I_{s c} \cdot F F$ dimana :

$P_{\max } \quad=$ Maximum power
$V_{o c}=$ open circuit voltage

$I_{S C}=$ short circuit current

$F F=$ Fill factor

From the observations obtained from the parameter data of the solar cell module. The data is then processed to determine the maximum power generated by the solar module as follows:

$$
\begin{aligned}
& V_{o c}=22,40 \mathrm{~V} \\
& I_{S c}=3,04 \mathrm{~A} \\
& F F \quad=0,72 \\
& \text { So }: P_{\max }=V_{o c} \cdot I_{s c} \cdot 0,72 \\
& =22.40 \mathrm{~V} \cdot 3.04 \mathrm{~A} \cdot 0,72=49,02 \mathrm{Watt}
\end{aligned}
$$

To calculate the value of $\mathrm{FF}$, an equation is used and the results can be calculated as follows:

$$
\begin{aligned}
& \mathrm{FF}=\frac{V_{m p} \cdot I_{m p}}{V_{o c} \cdot I_{s c}} \\
& \text { dimana }: F F=\text { Fill factor } \\
& V_{m p}=\text { max power voltage } \\
& I_{m p}=\text { max power current } \\
& V_{o c}=\text { open circuit voltage } \\
& I_{s c}=\text { short circuit current }
\end{aligned}
$$

From the observations obtained from the parameter data of the solar cell module. The data is then processed to determine the Fill Factor produced by the solar module as follows:

$$
\begin{aligned}
& V_{m p}=17,40 \mathrm{~V} \\
& I_{m p}=2.85 \mathrm{~A} \\
& V_{o c}=22 \cdot 40 \mathrm{~V} \\
& I_{s c}=3,04 \mathrm{~A} \\
& \text { So : FF }=\frac{V_{m p} \cdot I_{m p}}{V_{o c} I_{s c}} \\
& =\frac{17,40 \cdot 2,85}{22,40 \cdot 3,04}=0,72
\end{aligned}
$$


The calculation of Maximum Power (What can be generated by a 50 WP Polycristalline Solar Cell Panel, namely:

$$
\begin{aligned}
& V_{o c}=\text { open circuit voltage } \\
& I_{S C}=\text { short circuit current } \\
& F F=\text { Fill factor }
\end{aligned}
$$$$
P_{\max } \quad=V_{o c} \cdot I_{s c} \cdot F F
$$$$
\text { where: } \quad P_{\max }=\text { Daya maksimal }
$$

From the observations obtained from the parameter data of the solar cell module. The data is then processed to determine the maximum power generated $P_{\max }$ by the solar module as follows:

$$
\begin{aligned}
& V_{o c}=22,40 \mathrm{~V} \\
& I_{S C}=3,04 \mathrm{~A} \\
& F F=0,58
\end{aligned}
$$

So that: $P_{\max }=V_{o c} \cdot I_{s c} \cdot 0,58$

$$
=22.40 \mathrm{~V} .3 .04 \mathrm{~A} \cdot 0,58=39,49 \mathrm{Watt}
$$

To calculate the value of $\mathrm{FF}$, an equation is used and the results can be calculated as follows:

$\mathrm{FF}=\frac{V_{m p} \cdot I_{m p}}{V_{o c} \cdot I_{s c}}$

Where $: F F=$ Fill factor

$V_{m p}=$ Max power voltage

$I_{m p}=$ Max power current

$V_{o c}=$ Open circuit voltage

$$
I_{S C}=\text { Short circuit current }
$$

From the observations generated from the parameter data of the solar cell module. The data is then processed to determine the Fill Factor produced by the solar module as follows:

$$
\begin{aligned}
& V_{m p}=17,40 \mathrm{~V} \\
& I_{m p}=2.284 \mathrm{~A} \\
& V_{o c}=22.40 \mathrm{~V} \\
& I_{s c}=3,04 \mathrm{~A}
\end{aligned}
$$

So that :

$$
\begin{aligned}
& \mathrm{FF}=\frac{V_{m p} \cdot I_{m p}}{V_{o c} \cdot I_{S c}} \\
& =\frac{17,40 \cdot 2,284}{22,40 \cdot 3,04}=0,58
\end{aligned}
$$

\section{Solar cell Testing Graph}

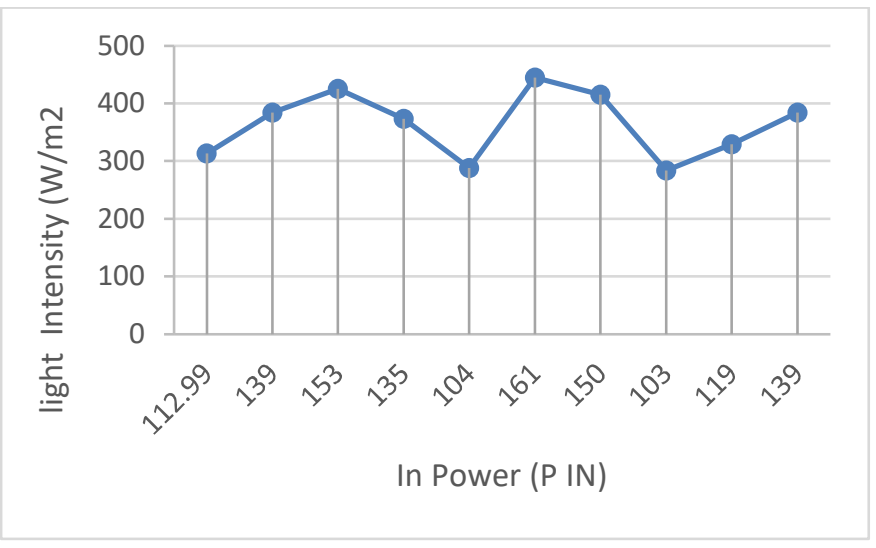

Figure 6. The graph of the amount of sunlight intensity and energy/power that enters the solar panel at $50 \mathrm{Wp}$.

In Figure 6, the results showed that the amount of energy that enters the solar panel is proportional to the area of the panel and the intensity of sunlight received by the panel. From the graphic image above, it can be seen that the trend of incoming energy is directly proportional to the intensity of sunlight.

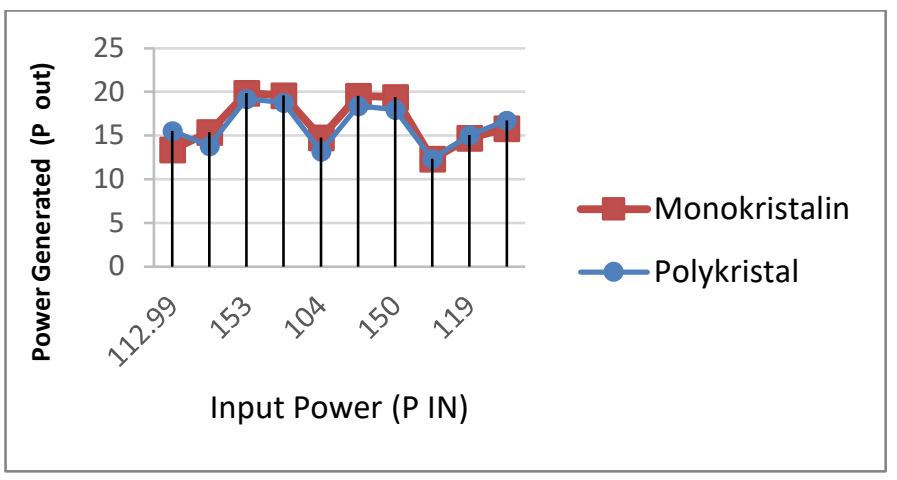

Figure 7. Graph of the relationship of energy entering the solar panel with the power generated from the $50 \mathrm{Wp}$ solar panel.

Meanwhile, from Figures 7 and 8, it can be seen that the amount of energy / power generated by the solar panel, both monocrystalline and polycrystalline, is directly proportional to the amount of energy entering the panel by following a pattern that forms an angle with the amount of energy entering. It can also be seen that the ability of monocrystalline materials to convert 
incoming energy into electrical energy that comes out is better than solar panels with polycrystalline materials.

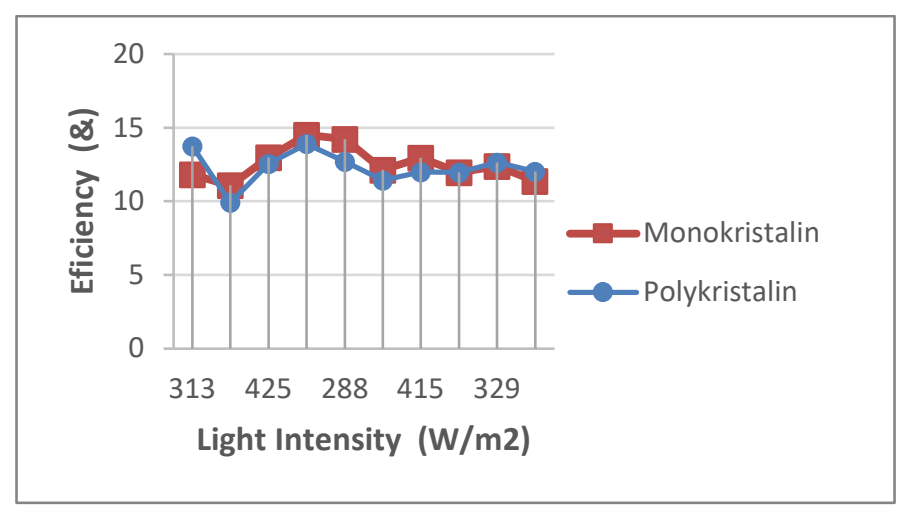

Figure 8. Graph of the relationship between the intensity of sunlight and the efficiency that occurs in a $50 \mathrm{Wp}$ solar panel.

If the average efficiency of monocrystalline and polycrystalline solar panels is taken during the test, then there is a difference in monocrystalline efficiency which is $0.25 \%$ higher than that of polycrystallines.

\section{Conclusion}

From the test results of two 50 WP Monocrystalline and Polycrystalline solar cell panels, the following conclusions can be taken:

1. The Efficiency Value of Solar Cell 50 WP Monocristalline type is higher than that of both Polycristalline at the same intensity.

2. Research conducted with varying light intensities to get the best efficiency value every hour, from the lowest light intensity to high light intensity with 313 and $445 \mathrm{~W} / \mathrm{m} 2$ with the distance of the light source to the solar cell, by getting the power data generated by the power plant solar. Changes in light intensity affect the voltage and current generated from solar cells. If the light intensity is increased, the current and voltage will increase.

3. The efficiency produced by the monocrystalline type solar cell is $14.51 \%$, while the polycrystalline type solar cell is $13.75 \%$. The electric voltage produced by a solar panel depends on the amount of radiation intensity it receives. Monocrystalline solar panels are able and better to convert the intensity of sunlight to energy entering the solar panel when compared to polycrystalline solar panels.

\section{Acknowledgement}

Authors wish to express their profound gratitude to the Rector of Universitas Muslim Indonesia, for their financial support and facilities of the laboratory.

\section{References}

[1] Md Faysal Nayan, S.M.Safayet Ullah, S. N. Saif, "Comparative Analysis of PV Module Efficiency for Different Types of Silicon Materials Considering the Effects of Environmental Parameters". 3rd International Conference on Electrical Engineering and Information Communication Technology (ICEEICT). 2016.

[2] C.Hemalatha, M.Valan Rajkumar, G.Vidhya Krishnan,."Simulation and Analysis of MPPT Control with Modified Firefly Algorithm for Photovoltaic System ".International Journal of Innovative Studies in Sciences and Engineering Technology (IJISSET) ISSN 2455-4863 (Online) www.ijisset.org Volume: 2 Issue: 11. November 2016.

[3] M.Lokanadham, "Incremental Conductance Based Maximum Power Point Tracking (MPPT) for P]hotovoltaic System", International Journal of Engineering Research and Applications (IJERA) Vol.2, pp.1420-1424, Mar-Apr 2012.

[4] C.F. Gabra, A. A. Hossam-Eldin, Ahmed Hamza H. Ali, "A Comparative Analysis Between the Performances of Monocrystalline,Polycrystalline and Amorphous Thin Film in Different Temperatures at Different Locations in Egypt". Conference, Africa Photovoltaic Solar Energy Conference (Africa PVSEC), Durban, South Africa. March 2014.

[5] Rizal Akbarudin Rahman, Aripriharta, Hari Putranto, "Performance Comparative Analysis of Monocrystalline and Polycrystalline Single Diode Solar Panel Models using the Five Parameters Method".Frontier Energy System and Power Engineering (FESPE), Vol. 1, No. 1. January 2019.

[6] Tarak Salmiet al., "Simulink Based Modelling of Solar Photovoltaic Cell", Vol.2, No.2, International Journal of Renewable Energy, Research Matlab. 2012.

[7] Nayan, Md Faysal, and S. M. Safayet Ullah, "Modelling of solar cell characteristics considering the effect of electrical and environmental parameters". Green Energy and Technology (ICGET), 3rd International Conference on. IEEE. 2015.

[8] Daniel T. Cotfas and Petru A. Cotfas, "Comparative Study of Two Commercial Photovoltaic Panels under Natural Sunlight Conditions". Hindawi International Journal of Photoenergy.Electrical Engineering and Computer Science Faculty, Transilvania University of Brasov, Romania. 22 Nov 2019.

[9] Eduard Muljadi, "Renewable Energy Solar PV - Electrical Characteristics". Workshop PV Tecnology Principle, Research and Application in Indonesia, Word Class Professor, Department of Electrical Engineering ITS, Surabaya,Auburn University. 2019. 